УДК 35.073.515.3

DOI https://doi.org/10.32849/2663-5313/2020.2.45

\author{
Анастасія Пекар, \\ здобувач \\ Науково-дослідного інституту інтелектуальної власності \\ Національної академії правових наук України
}

\title{
СПІВВІДНОШЕННЯ ПРАВОВИХ ІНСТИТУТІВ ПРАВ НА ЗАСОБИ ІНДИВІДУАЛІЗАЦІЇ ВІД НЕДОБРОСОВІСНОЇ КОНКУРЕНЩЇ
}

В умовах розвитку ринкової економіки широке використання засобів індивідуалізаиії сприяє створенню здорового конкурентного середовища. У статті розглянуто недобросовісну конкуренцію, пов'язану з придбанням та використанням виняткового права на засоби індивідуалізаиії. На підставі положень законодавства і правозастосовної практики проаналізовано ключові аспекти правового змісту иього феномена. Мета статті полягає в комплексному дослідженні проблеми співвідношення правових інститутів прав на засоби індивідуалізації від недобросовісної конкурениї, а також розробці теоретичних висновків і пропозицій щодо вдосконалення українського законодавства і правозастосовної практики у зазначеній сфері дослідження.

Основними висновками в межах ивого дослідження є такі:

1. Правовий захист від недобросовісної конкурениії є системно-структурованим утворенням, що охоплює нормативний і правозастосувальний складники. Нормативний складник характеризується специфікою поєднання матеріально-правових, процесуальних норм і норм, що регулюють функиії антимонопольних органів. Особливості правозастосувального складника правового захисту від недобросовісної конкурениії полягає в сформованій практиці поєднання адміністративних $і$ судових форм протидії недобросовісній конкурениії. Право на захист від недобросовісної конкурениії зумовлено участю в ринкових конкурентних відносинах, тому уповноваженою особою є господарюючий суб'єкт з моменту його виходу на відповідний товарний або фінансовий ринок з товарами, роботами, послугами.

2. Право на захист виняткового права і право на захист від недобросовісної конкурениї по-різному взаємодіють один з одним. На перетині недобросовісної конкурениї̈, пов'язаної з придбанням та використанням виняткового права на товарний знак, право на захист від недобросовісної конкуренції має пріоритет перед захистом виняткового права на товарний знак.

3. У межах захисту від недобросовісної конкурениії, пов'язаної з незаконним використанням засобів індивідуалізаиї в товарах, роботах, послугах, право на захист виняткового права збігається з правом на захист від недобросовісної конкуренції в частині припинення незаконного використання засобів індивідуалізації, тому правовласник може скористатися правом на захист від недобросовісної конкуренції та правом на захист виняткового права, обравши відповідно адміністративний або судовий порядок захисту. Тому власник права вправі реалізувати свої права на захист одночасно як правовласник $і$ як учасник конкурентних відносин. Така можливість створює сприятливі передумови для припинення недобросовісної конкурениії і захисту виняткових прав.

Ключові слова: правові інститути права, недобросовісна конкуренція, виняткове право, інтелектуальна власність, засоби індивідуалізації.

Постановка проблеми. В умовах розвитку ринкової економіки широке використання засобів індивідуалізації юридичних осіб, товарів, робіт, послуг і підприємств (далі - засобів індивідуалізації) сприяє створенню здорового конкурентного середовища. 3 одного боку, зростає ефективність підприємницької діяльності, підвищується якість i конкурентоспроможність товарів, робіт і послуг, а з іншого - збільшується кількість порушень прав на засоби індивідуалізації в результаті недобросовісної конкуренції, що чинить негативний вплив на всіх учасників цивільного обороту.

Забезпечення ефективного захисту прав на засоби індивідуалізації від недобросовісної конкуренції є пріоритетним напрямом розвитку українського законодавства. Пов'язана з цим теоретична і практична проблематика становить великий інтерес для наукового дослідження.

Правове регулювання в сфері захисту прав від недобросовісної конкуренції здійснюється нормами публічного і приват- 
ного, зокрема цивільного права. Положення цивільного законодавства в захисті прав на засоби індивідуалізації від недобросовісної конкуренції діють не відокремлено, а є в єдиній системі регулювання відносин у сфері захисту конкуренції, заснованої на загальних цілях і конституційному принципі неприпустимості недобросовісної конкуренції. Тому важливо визначити роль цивільно-правових способів захисту порушених недобросовісною конкуренцією прав на засоби індивідуалізації в наявній системі правових засобів припинення недобросовісної конкуренції, від ефективності яких значною мірою залежить дотримання правопорядку в підприємницькій сфері і загалом становлення цивілізованої економіки сучасної України.

Аналіз останніх досліджень і публікацій. Велике значення у проведенні дослідження мали роз'яснення Всесвітньої організації інтелектуальної власності (BОIВ) та роботи вчених-юристів і практиків, присвячені питанням застосування правової конструкції недобросовісної конкуренції та засобів індивідуалізації (М. Архипова, М. Богуславський, С. Кларк, І. Коваль, Е. Маркварта, Є. Харитонов, Т. Харт, Д. Хопкінс, Л. Цибенко, Р. Шишка та ін.). Також науковцями окреслені деякі шляхи припинення недобросовісної конкуренції в сфері виняткових прав як одного зі способів правової охорони промислової власності (Ю. Бошицький, Ю. Шемшученко). Обрана тематика дослідження зумовила необхідність аналізу наукових робіт, присвячених правовому інституту виняткових прав (А. Андрюшин, О. Бандурка, В. Білоус, О. Кузьменко, Т. Проценко, О. Ярмиш та ін.). Важливими для цілей цього дослідження також стали роботи науковцівцивілістів (О. Пастухов, О. Підопригора), науковців у галузі адміністративного та конституційного права (І. Арістова, О. Германова, I. Запорожець, Р. Калюжний, О. Копан, О. Мельник, О. Орлюк, В. Цимбалюк та ін.). Однак не досить розкритою залишається тематика значення правової конструкції недобросовісної конкуренції для цілей правової охорони виняткових прав на засоби індивідуалізації, а також співвідношення правових інститутів на засоби індивідуалізації від недобросовісної конкуренції.

З 3 огляду на це метою статті є комплексне дослідження проблеми співвідношення правових інститутів прав на засоби індивідуалізації від недобросовісної конкуренції, а також розробка теоретичних висновків і пропозицій щодо вдосконалення українського законодавства і правозастосувальної практики у зазначеній сфері дослідження.
Виклад матеріалу дослідження та його основні результати. В умовах ринкової економіки неабияке економічне значення має участь засобів індивідуалізації в цивільному обороті. Саме їх історична важливість зумовлює необхідність правового регулювання суспільних відносин стосовно прав на засоби індивідуалізації. Ключове місце в сфері регулювання приватно-правових відносин на засоби індивідуалізації посідає Цивільний кодекс України (далі - ЦК України) [1].

У міру посилення глобалізації наростає і конкуренція в різних сегментах світового ринку. Чим ширшою $є$ пропозиція і чим активніше ведеться боротьба за покупця, тим більшого значення набувають всі види засобів індивідуалізації - послуг, товарів, а також виробників. Засоби індивідуалізації та законодавчі механізми їхнього захисту забезпечують здорову ринкову конкуренцію і підвищення якості продукції.

Засобами індивідуалізації у всьому різноманітті їхніх видів є позначення, за допомогою яких комерційні фірми та їхня продукція (товари, послуги, певні роботи) ідентифікуються серед безлічі інших подібних об'єктів, набувають унікальності. Однак у Цивільному кодексі України чітке визначення засобів індивідуалізації відсутнє, є лише перерахування i характеристики їх окремих видів [1]. Усі ці об'єкти цивільних прав мають одну загальну особливість: їх застосування обмежене комерційним оборотом. 3 огляду на це власниками майнових прав на будь-які види засобів індивідуалізації не можуть бути громадяни, які не здійснюють комерційну діяльність. Окрім того, всі засоби індивідуалізації поділяються на три види за типом їхнього власника:

1) засоби індивідуалізації юридичних осіб (назви підприємств);

2) інструменти ідентифікації, що використовуються в комерційній діяльності і підлягають реєстрації в державних органах (назви місць походження товару, наприклад).

3) засоби індивідуалізації окремих товарів (брендів, товарних лінійок тощо) або цілих фірм або ІП (знаки обслуговування, товарні знаки).

Загалом інститут засобів індивідуалізації в цивільному обороті є сукупністю правових норм, що охороняють такі об' єкти: комерційне (формове) найменування, торговельну марку, найменування місця походження товару.

Таким чином, засоби індивідуалізації учасників цивільного обороту, товарів та послуг, що належать до об'єктів інтелектуальної власності (комерційні найменування, торговельні марки та географічні зазна- 
чення), формують особливу групу індивідуалізуючих найменувань, самостійну стосовно інших видів ідентифікуючих позначень, відносини у сфері використання яких регулюються правовими нормами. Охоронювані Цивільним кодексом засоби індивідуалізації не слід тлумачити ізольовано та відокремлено від інших об'єктів правової охорони. Водночас комерційні найменування, торговельні марки та географічні зазначення тісно пов'язані 3 результатами інтелектуальної творчої діяльності та з іншими знаряддями індивідуалізації суб'єктів чи об'єктів цивільного права. Зазначені позначення утворюють систему, що характеризується взаємозумовленістю, внутрішньою єдністю і цілісністю iii елементів, зв'язками та залежністю від зовнішніх чинників та процесів. Разом із тим вони становлять невід'ємну частину більш значних комплексів упорядкованих елементів - системи об'єктів права інтелектуальної власності та системи засобів індивідуалізації.

ЦК України встановлює правову охорону трьох основних видів засобів індивідуалізації: комерційних найменувань, торговельних марок та географічних зазначень. Окрім закріплення в ЦК, відносини у галузі використання торговельних марок та географічних зазначень знайшли своє закріплення ще й в спеціальних законах: законах України «Про охорону прав на знаки для товарів і послуг» [2] та «Про охорону прав на зазначення походження товарів» [3]. Звісно, законодавство у сфері охорони засобів індивідуалізації потребує оновлення та доповнення, що, передусім, спричинено швидким розвитком економічних відносин у цій сфері.

Засоби індивідуалізації розглядаються у ЦК України у єдиному ракурсі, на них поширюються загальні положення правової охорони (Глава 35 ЦК), тому можна констатувати спільність правових конструкцій та механізмів регулювання відносин, пов'язаних 3 використанням комерційних найменувань, торговельних марок та географічних зазначень, якими, враховуючи вищенаведені положення, не можуть вважатися ті, що застосуються у рамках інституту власності [4].

3 розвитком ринкових відносин загострюється конкурентна боротьба, що набуває різні прояви, тому врегулювати виникаючі правовідносини лише за допомогою конкретних правових норм імперативного і диспозитивного характеру видається вельми скрутно. Усе це є підставою для вироблення правової конструкції недобросовісної конкуренції. Ключовим джерелом правового регулювання питань запобігання недобросовісної конкуренції є Паризька конвенція з охорони промислової власності від 1883 року [5], яка встановила концепцію загальної заборони на недобросовісну конкуренцію, тобто на будь-які акти конкуренції, що суперечать чесним звичаям у промислових і торговельних справах, і виділила найпоширеніші ї̈ види у формі окремих заборон. Як слушно зазначає J. Turner, недобросовісною конкуренцією визнаються дії, пов'язані з придбанням та використанням виняткового права на засоби індивідуалізації, які формально здійснюються в рамках закону, але порушують уявлення суспільства щодо моральності учасників цивільного обороту [6]. Тобто такі дії спрямовані на отримання необгрунтованих переваг у конкурентній боротьбі за рахунок використання відомих позначень і іміджу підприємців, які позитивно зарекомендували себе серед споживачів і контрагентів.

Отже, недобросовісну конкуренцію слід розглядати як широкий спектр видів опортуністичної поведінки фактичних і потенційних учасників товарних ринків, що завдає шкоди конкурентам i/або споживачам у процесі суперництва на ринку, за ринок або в зв'язку з входом на ринок (виходом з ринку). Точніше визначення недобросовісної конкуренції дати важко через відсутність 3 цього приводу міжнародного консенсусу. У недавньому дослідженні N. Lee зазначає, що питання щодо розуміння недобросовісної конкуренції в повсякденній мові й про можливості включення цієї концепції в правову систему в різних країнах є досить різними.

У Великобританії недобросовісна конкуренція як така часто не розглядається як правопорушення, хоча окремі їі види цілком можуть підлягати санкціям. У континентальній Європі концепція недобросовісної конкуренції визнається юридичною спільнотою, але поняття «недобросовісна конкуренція» та їі місце в правовій системі залишаються дещо загадковими, принаймні 3 позицій порівняльного аналізу [7].

Недобросовісна конкуренція як опортуністична поведінка заснована на наявності асиметрії інформації. У різних класифікаціях $[8 ; 9 ; 10]$ виокремлюються кілька типів асиметрії інформації, які, на нашу думку, зводяться до таких типів:

1) приховані характеристики благ і контрагентів (у різних джерелах - прихована інформація, приховані знання еx ante) часто спричинюють несприятливий (гірший) відбір;

2) приховані дії контрагентів часто зумовлюють суб'єктивний ризик, тобто схильність до невиконання/неправильного виконання/ неповного виконання контрактів;

3) прихована інформація (нерівність у доступі до інформації ex post, під час здій- 
снення відносин 3 партнером) також веде до суб'єктивного ризику;

4) приховані наміри, які часто породжують стимули починати відносини з партнером задля вимагання у нього в майбутньому, якщо цей партнер не може перервати відносини з огляду на зроблені інвестиції в специфічні активи.

Основною ознакою правової конструкції недобросовісної конкуренції в сфері виняткових прав на засоби індивідуалізації є отримання недобросовісним конкурентом переваг у підприємницькій діяльності за рахунок неправомірного використання комерційної цінності і популярності засобів індивідуалізації інших господарюючих суб'єктів, вироблених ними товарів або послуг. Недобросовісна конкуренція має місце тоді, коли не тільки придбано виняткове право, а й розпочато використання засобу індивідуалізації в цивільному обороті $з$ метою отримання переваг за рахунок використання популярності позначення, створеної іншим господарюючим суб'єктом.

Здійснивши невеликий аналіз правової природи засобів індивідуалізації як об'єктів інтелектуальної власності, варто зупинитися на не менш важливому питанні, а саме на співвідношенні правових інститутів засобів індивідуалізації та недобросовісної конкуренції. Так, А. Сергєєв вважає, що інститут захисту від недобросовісної конкуренції самостійного правового інституту не складає, а є складовою частиною інституту права інтелектуальної власності [11]. Такий підхід зумовлений тим, що, по-перше, право на захист від недобросовісної конкуренції як об'єкт правової охорони є будь-який інститут права інтелектуальної власності, по-друге, основним виявом актів недобросовісної конкуренції є посягання на об'єкти інтелектуальної власності, які підлягають правовій охороні; по-третє, низький рівень розвитку законодавства у цій сфері.

Певною мірою подібна позиція щодо співвідношення інституту правового захисту від недобросовісної конкуренції та інституту правової охорони інтелектуальної власності трапляється і у інших науковців. Так, наприклад, М. Цвєткова стверджує, що недобросовісна конкуренція, яка характеризується наявністю певних встановлених законодавством ознак, є й окремим випадком незаконного використання фірмового найменування [10]. Водночас норми закону про захист конкуренції, що містять заборону на недобросовісну конкуренцію, тільки доповнюють положення Цивільного кодексу, вводячи адміністративний порядок захисту виняткових прав.
Питання співвідношення законодавства про захист від недобросовісної конкуренції та про інтелектуальну власність є досить актуальним, оскільки вони перебувають у межах правового поля, юристам необхідно захищати підприємців, бізнесу яких завдано збитків або руйнування безліччю виявів недобросовісної конкуренції, що випливає зі сфери торгових знаків і найменувань. Це актуалізує необхідність здійснення аналізу взаємозв'язку двох правових інститутів, керуючись принципом від протилежного, а саме виявити: чи є інститут правової охорони інтелектуальної власності складовою частиною інституту захисту від недобросовісної конкуренції.

Відмінність між контрафактними діями за законодавством про захист конкуренції та законодавством про захист виняткових прав інтелектуальної власності полягає у наслідках, які настають у результаті здійснення контрафактних дій. Так, за законодавством про захист конкуренції наслідками є реальні або потенційні збитки, або ж прямі та непрямі збитки, завдані діловій репутації. У випадку із законодавством про захист виключних прав інтелектуальної власності йдеться саме про порушення виняткових прав на засіб індивідуалізації або ж на інший результат інтелектуальної діяльності. Тобто найяскравіший взаємозв'язок виявляється саме із засобами індивідуалізації.

Підтвердженням цього аргументу $€$ та персоніфікуюча функція, яка відведена фірмовим найменуванням, товарним знакам, найменуванням місць походження товарів та комерційним позначенням, а також обмеження видів суб'єктів, які можуть бути правовласниками таких засобів індивідуалізації.

Зауважимо, що взаємозв'язок інститутів захисту від недобросовісної конкуренції з інститутом правової охорони засобів індивідуалізації тією чи іншою мірою визнаний у науці. Це зумовлено тим, що відокремлювати принципи охорони від незаконного використання товарного знака від принципів захисту від недобросовісної конкуренції є неправильним, оскільки ці принципи мають одну сутність - контроль за можливістю здійснення дій, спрямованих на обман. Тому законодавство про товарні знаки є підгалуззю законодавства про захист від недобросовісної конкуренції.

3 моменту виникнення нової конструкції власності (права інтелектуальної власності) з метою правової охорони інтересів господарюючих суб'єктів у рамках підприємницької діяльності законодавство про товарні знаки було кваліфіковано як складову частину законодавства про захист від недобросовісної 
конкуренції [12]. Правова охорона від незаконного використання надається автоматично в разі реєстрації товарного знака, тоді як механізми правового захисту від виникнення змішання набагато ширші і поширюються на ділову репутацію загалом, включаючи найменування товарів або послуг, методи ведення бізнесу, зовнішне оформлення товару або маркетинговий стиль

Конкурентне право в цьому разі не є додатковим способом захисту виняткових прав та не має складати конкуренцію цивільно-правовим методам регулювання, закладеним у спеціальних законах, оскільки застосування антимонопольного законодавства можливе лише в тих випадках, коли порушення законодавства про виняткові права пов'язано з порушенням принципів добросовісної конкуренції [13]. Можливість існування цього взаємозв'язку, а певною мірою і елементів підпорядкування одного правового інституту іншому, виникає тільки тоді, коли правовідносини з незаконного використання тих чи інших об'єктів інтелектуальної власності виникають у рамках конкурентної боротьби між господарюючими суб'єктами в підприємницькій діяльності, пов'язаній з виробництвом товарів або наданням послуг і зумовленій цілями отримання переваг у підприємницькій діяльності способами недобросовісними, нерозумними і несправедливими [14].

Отже, припускаємо, що інститут захисту від недобросовісної конкуренції є ключовим правовим інститутом захисту виняткових прав на засоби індивідуалізації. Усі вищезазначені правові інститути є вкрай важливими в умовах стрімкого розвитку ринкових відносин та посиленої конкурентної боротьби. Проте інститут захисту від недобросовісної конкуренції не обмежується захистом лише засобів індивідуалізації, а має слугувати механізмом захисту від недобросовісного використання й інших позначень, що використовуються господарюючими суб'єктами на ринку, зокрема об'єктів промислової власності, винаходів, корисних моделей, промислових зразків, селекційних досягнень, а також об'єктів авторського права за умов їхнього незаконного використання в конкурентній ринковій боротьбі.

Отже, саме легальне визначення недобросовісної конкуренції та сутність правової конструкції такого інституту дають змогу нам перш за все стверджувати, що інститут правового захисту від недобросовісної конкуренції значно ширший інституту правової охорони інтелектуальної власності, спрямований на правове регулювання відносин, що виникають не тільки в сфері незаконного використання виключних прав, що підлягають правовій охороні, а й будь-яких інших правовідносин, що виникають у конкурентному суперництві господарюючих суб'єктів під час здійснення підприємницької діяльності на тому чи іншому товарному ринку, якщо в межах цього суперництва починають використовуватися недобросовісні прийоми і засоби, що тягнуть або можуть спричиняти несприятливі наслідки для конкурента і конкуренції на товарному ринку загалом.

\section{Висновки}

Таким чином, поняття недобросовісної конкуренції виходить за рамки захисту виключно засобів індивідуалізації, є значно ширшим. Водночас не варто залишати поза увагою і той факт, що у разі порушення прав володільців засобів індивідуалізації їхній захист може відбуватися не лише в рамках законодавства про захист від недобросовісної конкуренції, а й загальними способами захисту, передбаченими Цивільним кодексом України.

На жаль, питання визначення способів захисту прав володільців інтелектуальної власності та засобів індивідуалізації зокрема, хоч і залишається актуальним, проте досі так і не знайшло свого нормативного закріплення. Тому пропонуємо на законодавчому рівні це питання врегулювати, а саме доповнити Цивільний кодекс України статтею такого змісту: «Захист прав на результат інтелектуальної діяльності або на засіб індивідуалізації від недобросовісного використання (недобросовісної конкуренції) може бути здійснений не тільки способами, визначеними цим Кодексом, а й відповідно до законодавства про захист від недобросовісної конкуренції».

Проведене дослідження дає змогу зробити висновок, що, незважаючи на наявність у чинному законодавстві блоку норм, які регулюють відносини з приводу припинення недобросовісної конкуренції, певні проблеми в сфері охорони засобів індивідуалізації залишаються і потребують подальшого вирішення.

\section{Список використаних джерел:}

1. Цивільний кодекс України : Закон України від 16.01.2003 р. № 435-IV. URL: https://zakon. rada.gov.ua/laws/show/435-15 (дата звернення: 31.01.2020).

2. Про охорону прав на знаки для товарів і послуг : Закон України від 23.12.1993 р. № 3689-XII. URL: https://zakon.rada.gov.ua/laws/ show/3689-12 (дата звернення: 31.01.2020).

3. Про охорону прав назазначення походження товарів : Закон України від 16.06.1999 № 752-XIV. 
URL: https://zakon.rada.gov.ua/laws/show/752-14 (дата звернення: 31.01.2020).

4. Кодинець А.О. Захист прав інтелектуальної власності в умовах впровадження судової реформи. Підприємниитво, господарство і право, 2018. № 3. С. $9-13$.

5. Парижская конвенция по охране промышленной собственности от 20.031883 г. URL: https://www.wipo.int/edocs/lexdocs/treaties/ $\mathrm{ru} /$ paris/trt_paris_001ru.pdf (дата обращения: $31.01 .2020)$.

6. Turner Jonathan D.C. Intellectual Property and EU Competition Law, 2 u. Oxford University Press, Oxford, 2015. 48 p.

7. Intellectual property, unfair competition and publicity: convergences and development / N. Lee, et al., eds. Edward Elgar Publishing, 2014. 49 p.

8. Zhang L. Intellectual property strategy and the long tail: Evidence from the recorded music industry. Management Science. 2018. Vol. 64(1). P. 24-42.

9. Мельник О.М. Цивільно-правова охорона інтелектуальної власності в Україні : автореф. дис. ... д-ра юрид. наук : 12.00.03. НАН України,
Ін-т держави і права ім. В.М. Корецького. Київ, 2004. 36 c.

10. Цветкова М.В. Гражданско-правовая защита прав на средства индивидуализации от недобросовестной конкуренции : диссертация ... кандидата юридических наук : 12.00.03. Рос. правовая акад. М-ва юстиции РФ. Москва, 2011.197 с

11. Сергеев А.П. Право интеллектуальной собственности в Российской Федерации : учебник для студентов вузов, обучающихся по специальности «Юриспруденция». 2. изд., перераб. и доп. Москва : Проспект, 2003 (ОАО Яросл. полигр. комб.). $750 \mathrm{c}$

12. Кубах А.І. Право інтелектуальної власності : навчальний посібник. Харків : ХНАМГ, 2008. 149 c.

13. Смерницький Д.В. Інститут інтелектуальної власності: теоретико-правова характеристика. Криміналістичний вісник. 2014. № 2. С. 37-47.

14. Артеменко Л.В. Особливості правового регулювання засобів індивідуалізації учасників цивільного обороту, товарів та послуг. Акту альні проблеми вітчизняної юриспруденції. 2016. Вип. 1. С. 16-22.

In the conditions of market economy development, widespread use of means of individualization contributes to creation of fair competitive environment. The article deals with unfair competition related to the acquisition and use of the exclusive right to means of individualization. Based on the provisions of the legislation and law enforcement practice, the key aspects of the legal content of this phenomenon were analyzed.

The objective of the article is to comprehensively study the problem of the relationship of legal institutions of the rights to the means of individualization against unfair competition, as well as to develop theoretical conclusions and proposals for the improvement of Ukrainian legislation and law practice in this field of research.

The main findings of this study are as follows:

1. Legal protection against un fair competition is a system-structured formation thatencompassesregulatory and enforcement components. The regulatory component is characterized by specifics of the combination of the rules of substantive law, procedural rules and rules governing the functions of antimonopoly bodies. The peculiarities of the enforcement component of legal protection against unfair competition are the established practice of combining administrative and judicial forms of counteraction to unfair competition. The right to protection against unfair competition is conditioned by participation in market competitive relations, so the authorized person is an economic entity from the moment of its entry into the relevant commodity or financial market with goods, works, services.

2. The right to the protection of the exclusive right and the right to protection against unfair competition interact in different ways. At the intersection of unfair competition associated with the acquisition and use of the exclusive right to a trademark, the right to protection against unfair competition takes priority over the protection of the exclusive right to a trademark.

3. In the framework of protection against unfair competition related to the illegal use of the means of individualization in goods, works, services, the right to the protection of the exclusive right coincides with the right to protection against unfair competition as regards termination of the illegal use of the means of individualization, so the right holder may use protection against unfair competition and the right to the protection of exclusive rights, having chosen, respectively, an administrative or judicial protection procedure. Therefore, the right holder is entitled to exercise his rights to protection both as the right holder and as a party to competitive relations. Such an opportunity creates favourable conditions for ending unfair competition and protecting exclusive rights.

Key words: legal institutes, unfair competition, exclusive right, intellectual property, means of individualization. 